\title{
KEMAMPUAN PENALARAN MATEMATIS PESERTA DIDIK MELALUI MODEL PEMBELAJARAN RECIPROCAL TEACHING DENGAN BERBANTUAN ALAT PERAGA "KARTU PINTAR" PADA MATERI PRISMA DAN LIMAS KELAS VIII SMP NEGERI 1 PANDAAN TAHUN AJARAN 2017/2018
}

\author{
Putri Amalia Cahyani ${ }^{1}$ \\ ${ }^{1}$ SMP Negeri 1 Pandaan Pasuruan \\ Email: ' putriamaliacahyani@gmail.com
}

\begin{abstract}
Abstrak
Penelitian ini bertujuan untuk mengetahui apakah terdapat peningkatan kemampuan penalaran matematis dan untuk mendeskripsikan kemampuan penalaran matematis peserta didik melalui model pembelajaran Reciprocal Teaching dengan berbantuan alat peraga "kartu pintar" pada materi prisma dan limas kelas VIII SMP Negeri 1 Pandaan Tahun Pelajaran 2017/2018. Metode penelitian yang digunakan dalam penelitian ini yaitu metode kombinasi (mixed methods) dengan desain rancangan metode campuran eksperimental adalah membungkus suatu rancanagan metode campuran dasar kedalam strategi yang lebih lanjut, yaitu dengan menambahkan proses-proses kedalam prosedur eksperimen. Hasil penelitian menunjukkan bahwa Berdasarkan hasil analisis data kuantitatif diperoleh kesimpulan bahwa terdapat peningkatan antara kemampuan penalaran matematis sebelum dan sesudah menggunakan model pembelajaran Reciprocal Teaching dengan berbantuan alat peraga "kartu pintar" pada materi prisma dan limas kelas VIII di SMP Negeri 1 Pandaan. Dari beberapa analisis data tesebut menunjukkan bahwa kemampuan penalaran matematis meningkat setelah penerapan model pembelajaran Reciprocal Teaching dengan berbantuan alat peraga "kartu pintar".
\end{abstract}

Kata Kunci: pendidikan, kurikulum 2013, model pembelajaran Reciprocal Teaching, kemampuan penalaran matematis, alat peraga.

\section{Abstract}

The purpose of this study was to determine whether there is an increase in mathematical reasoning abilities and to describe the mathematical reasoning abilities of students through the Reciprocal Teaching learning model assisted with "smart card" teaching aids on prism and pyramid material class VIII Public Middle School 1 Pandaan 2017/2018 Academic Year. The research method used in this study, which is a mixed method with an experimental mixed method design design, was to wrap a basic mixed method design into a further strategy, namely by adding processes into the experimental procedure. The results showed that based on the results of quantitative data analysis, it was concluded that there was an increase between mathematical reasoning abilities before and after using the Reciprocal Teaching learning model with the help of "smart card" teaching aids on class VIII prism and pyramid material in Pandaan 1 Public Middle School. From some of the data analysis shows that mathematical reasoning ability increases after the application of the Reciprocal Teaching learning model with the help of "smart card" teaching aids.

Keywords: education, 2013 curriculum, Reciprocal Teaching learning model, mathematical reasoning ability, teaching aids.

\section{PENDAHULUAN}

Pendidikan adalah salah satu bagian terpenting dalam kehidupan manusia. Pendidikan juga merupakan cara dalam mewujudkan tujuan yang telah ditentukan sebelumnya. Hal ini tercantum dalam Undang-undang Sistem Pendidikan Nasional Nomor 20 Tahun 2003 yang mengemukakan bahwa pendidikan merupakan suatu cara dan konsep dalam mewujudkan situasi dan sistem pembelajaran yang dimana peserta didik dapat menumbuh kembangkan kemampuan diri dengan aktif dalam kecerdasan, ketrampilan, kekuatan spiritual keagamaan, kepribadian dan akhlak mulia untuk mencerdaskan kehidupan bangsa dan negara. Sejalan dengan hal tersebut, pemerintah berusaha meningkatkan kualitas pendidikan dengan menginovasi berbagai bidang, seperti bidang sistem pendidikan, kurikulum, metode pengajaran, peningkatan kualitas guru dan buku pelajaran.

Kurikulum merupakan salah satu faktor yang dapat memberikan kontribusi signifikan dalam mewujudkan proses untuk meningkatkan kemampuan peserta didik. Kurikulum 2013 yang telah ditetapkan menitikberatkan pada kegiatan pembelajaran yang melibatkan peran aktif peserta didik yaitu dengan menggunakan pendekatan saintifik. Pada salah satu kompetensi dasarnya, 
terdapat tujuan umum pembelajaran matematika yang dirumuskan dalam Permendiknas Nomor 22 Tahun 2006 tentang Standar Isi.

Berdasarkan tujuan umum pembelajaran matematika tersebut, terlihat bahwa kurikulum yang disusun sudah memperhatikan aspek pengembangan kemampuan penalaran matematis peserta didik. Depdiknas (dalam Triastuti, 2013:183), mengemukakan bahwa "materi matematika dan penalaran matematika adalah dua hal yang erat kaitannya. Kemampuan bernalar tidak hanya dibutuhkan peserta didik untuk memecahkan masalah dan mengambil kesimpulan dalam permasalahan hidup." Oleh karena itu, peserta didik dituntut memiliki kemampuan penalaran.

Namun kondisi saat ini dalam pembelajaran matematika disekolah menunjukkan bahwa kemampuan panalaran matematis masih dianggap kurang dan belum ditekankan secara khusus (dalam Kemendikbud, 2016). Hal ini dapat dilihat dari laporan survei The Trends in International Mathematics and Science Study (TIMSS) dan Programme for International Student Assesment (PISA) yang menunjukkan rendahnya nilai rata-rata matematis dari peserta didik di Indonesia masih rendah. Indonesia mengikuti TIMSS pada tahun 1999, 2003, 2007, 2011 dan 2015. Sedangkan PISA pada tahun 2000, 2003, 3006, 2012 dan 2015. Hasil survei PISA terbaru pada tahun 2015 menunjukkan kemampuan matematika peserta didik Indonesia menempati peringkat 63 dari 70 negara (OECD, 2016). Sementara itu hasil dari studi TIMSS tahun 2015 menunjukkan prestasi matematika peserta didik Indonesia berada pada peringkat 44 dari 49 negara (IEA, 2016).

Sedangkan hasil wawancara yang dilakukan peneliti dengan salah seorang guru mata pelajaran matematika SMP Negeri 1 Pandaan yaitu Ibu Zakiatus Qurrotul A'yun, S.Pd. pada tanggal 7 April 2018, diperoleh informasi bahwa pembelajaran yang dilakukan masih menggunakan pembelajaran konvensional atau pembelajaran langsung. Selain itu proses pembelajaran belum menekankan pada kemampuan penalaran matematis peserta didik secara khusus. Dari hasil pre-test kemampuan penalaran matematis yang telah dilakukan sebelum perlakuan pada tanggal 27 April 2018 terlihat bahwa peserta didik kelas VIII H tidak ada yang memperoleh nilai $\geq 75$ yang merupakan nilai KKM yang digunakan sekolah. Nilai tertinggi yang diperoleh dari kedua kelas yaitu 47 .

Berdasarkan fakta yang telah diuraikan diatas, kemampuan penalaran matematis peserta didik masih rendah dikarenakan beberapa faktor, salah satu faktornya yaitu proses pembelajaran yang masih terpusat pada guru dengan menggunakan pembelajaran ekspositori. Pembelajaran eksposisitori adalah pembelajaran yang berpusat pada guru, dimana perilaku guru dalam menjelaskan kepada peserta didik kurang kreatif dan menyebabkan pembelajaran menjadi membosankan. Guru juga menyampaikan materi dengan cara memberikan penjelasan tentang konsep suatu materi dan memberikan soal latihan sehingga konsep yang didapatkan peserta didik pun hanya terpaku pada penjelasan guru karena peserta didik tidak diberikan kesempatan untuk mengenal konsep secara mandiri. Sedangkan cara penyampaian materi yang disampaikan oleh guru dapat berpengaruh pada penalaran matematis peserta didik.

Menyikapi permasalahan tentang kemampuan penalaran matematis peserta didik yang masih rendah maka diperlukan perbaikan dalam proses pembelajaran. Salah satu cara untuk melatih peserta didik dalam bernalaran yaitu dengan memilih suatu model pembelajaran yang lebih menekankan kepada kemampuan penalaran matematis. Model pembelajaran yang tepat akan menjadikan peserta didik tidak merasa bosan dan situasi belajar lebih menyenangkan, sehingga tujuan pembelajaran dapat tercapai serta tidak hanya belajar menghafal tetapi juga memahami. Alternatif model pembelajaran yang ditawarkan dalam hal ini adalah dengan menerapkan model pembelajaran Reciprocal Teaching.

Menurut Pannen (dalam Amin, 2006:34), reciprocal teaching adalah model pembelajaran terbalik, dengan model pembelajaran ini peserta didik diharapkan dapat mengembangkan kemauan belajar dan pengetahuan secara mandiri, serta guru berperan sebagai fasilitator, mediator, dan manager dalam proses pembelajaran. Kaitannnya dengan model pembelajaran Reciprocal Teaching yang dimana peserta didik beperan sebagai "guru" untuk menyampaikan materi kepada teman-temannya. Sebagai penunjang proses pembelajaran perlu adanya alat peraga yang memadai. Menurut Nasaruddin (2015:21), alat peraga adalah alat yang digunakan untuk menerangkan atau mewujudkan konsep matematika. Alat peraga yang dimaksud adalah alat bantu yang digunakan untuk memperlancar pembelajaran matematika. Alat peraga juga diharapkan peserta didik diharapkan dapat memahami konsep sebaik-baiknya, maka dalam pembelajarannya peserta diberi kesempatan untuk mengkonstruksi pengetahuannya sendiri yang diantaranya melalui pemanipulasian alat peraga.

Alat peraga "Kartu Pintar" merupakan alat peraga dua dimensi yang dirancang khusus oleh peneliti untuk membantu proses pembelajaran. Alat peraga ini didesain semenarik mungkin agar dapat memberikan motivasi, rangsangan, kejelasan dan interaksi antar peserta didik. Alat peraga tersebut juga digunakan agar dapat membantu peserta didik dalam menyampaikan materi 
sehingga materi yang akan disampaikan lebih terfokus. Dimana alat peraga "kartu pintar" ini sangatlah cocok untuk media pembelajaran dengan menggunakan model pembelajaran Reciprocal Teaching.

Tujuan penelitian ini adalah (1) Untuk mengetahui apakah terdapat peningkatan kemampuan penalaran matematis peserta didik melalui model pembelajaran Reciprocal Teaching dengan berbantuan alat peraga "kartu pintar" pada materi prisma dan limas kelas VIII SMP Negeri 1 Pandaan Tahun Pelajaran 2017/2018; (2) Untuk mendeskripsikan kemampuan penalaran matematis peserta didik melalui model pembelajaran Reciprocal Teaching dengan berbantuan alat peraga "kartu pintar" pada materi prisma dan limas kelas VIII SMP Negeri 1 Pandaan Tahun Pelajaran 2017/2018.

\section{METODE}

Pendekatan yang digunakan dalam penelitian ini yaitu pendekatan dengan Metode penelitian yang digunakan dalam penelitian ini yaitu metode kombinasi (mixed methods) dengan desain rancangan metode campuran eksperimental. Dimana rancangan metode campuran ekspermental adalah membungkus suatu rancanagan metode campuran dasar kedalam strategi yang lebih lanjut, yaitu dengan menambahkan proses-proses kedalam prosedur eksperimen. Sehingga dalam penelitian ini bertujuan untuk mengetahui kemampuan penalaran matematis peserta didik melalui model pembelajaran Reciprocal Teaching dengan berbantuan alat peraga "kartu pintar" serta mendeskripsikan analisis kemampuan penalaran matematis peserta didik melalui model pembelajaran Reciprocal Teaching dengan berbantuan alat peraga "kartu pintar".

Lokasi yang digunakan dalam penelitian ini yaitu SMP Negeri 1 Pandaan, populasi dalam penelitian ini yaitu seluruh peserta didik kelas VIII SMP Negeri 1 Pandaan, sampel penelitian yang digunakan dalam penelitian ini dipilih melalui teknik Purposive Sampling dan terpilihlah kelas VII H SMP Negeri 1 Pandaan yang terdiri dari 32 peserta didik.

\section{Metode Penelitian Kuantitatif}

Penelitian kuantitaif ini menggunakan jenis penelitian eksperimen dengan desain penelitian menggunakan One Group Pretest-Posttest Design. Sampel penelitian ini menggunakan satu kelas, yaitu kelas VIII H sebagai kelas eksperimen sekaligus kelas kontrol untuk dirinya sendiri yang diajarkan menggunakan model pembelajaran Reciprocal Teaching dengan berbantuan alat peraga "kartu pintar". Teknik pengumpulan data kuantitatif dilakukan dengan metode tes. Metode tes tersebut digunakan untuk memperoleh data tentang kemampuan penalaran matematis peserta didik dalam pembelajaran matematika sebelum dan sesudah dikenai perlakuan. Tes yang diberikan adalah soal pre-test dan post-test yang berupa soal uraian. Sebelum dimulai pembelajaran, kelas eksperimen diberi tes awal atau pre-test untuk mengukur kondisi awal kemampuan penalaran matematis peserta didik. Selanjutnya kelas eksperimen diberi perlakuan pembelajaran dengan model pembelajaran Reciprocal Teaching dengan berbantuan alat peraga "kartu pintar". Setelah selesai pembelajaran, kelas eksperimen diberi tes akhir atau post-test untuk mengukur kondisi akhir kemampuan penalaran matematis peserta didik. Instrumen yang digunakan dalam penelitian ini berupa soal tes kemampuan penalaran matematis peserta didik berupa soal uraian dan terdiri dari 4 item yang memuat indikator kemampuan penalaran matematis. Soal tes telah diuji validitas dan reliabilitas. Analisis data yang digunakan uji normalitas dan uji hipotesis menggunakan software SPSS 23 dan software minitab 17.

\section{Metode Penelitian Kualitatif}

Pada penelitian ini jenis penelitian kualitatif yang digunakan adalah deskriptif kualitatif, yaitu suatu prosedur penelitian yang menggunakan data deskriptif berupa kata-kata tertulis atau lisan dari orang-orang dan pelaku yang dapat diamati. Subjek penelitian kualitatif (subjek wawancara) ini dipilih berdasarkan hasil tes kemampuan penalaran matematis dan dikelompokkan menjadi tiga kriteria yaitu peserta didik dengan kemampuan penalaran matematis tinggi, sedang, dan rendah. Sedangkan yang menjadi objek penelitian yaitu penggunaan model pembelajaran Reciprocal Teaching dengan berbantuan alat peraga "kartu pintar" dalam melatih kemampuan penalaran matematis peserta didik. Teknik pengumpulan data yang digunakan yaitu observasi, wawancara, dan catatan lapangan yang telah di validasi oleh ahli yaitu Bapak Abdul Halim Fathani, S.Si., M.Pd. dan praktisi yaitu Ibu Zakiatus Qurrotul A'yun, S.Pd. Teknik analisis data yang digunakan dilapangan menggunakan model Miles dan Huberman yaitu yaitu data reduction, data display, dan conclusion drawing/ verification. Uji keabsahan data yang digunakan yaitu metode triangulasi. 


\section{Analisis Data Kuantitatif dan Kualitatif}

Setelah uraian analisis data secara kuantitatif dan kualitatif dilakukan dengan cara menelaah hubungan dan membandingkan kedua data tersebut apakah saling memperkuat, melengkapi, memperluas, memperdalam atau malah bertentangan dengan kemampuan penalaran matematis peserta didik melalui model pembelajaran reciprocal teaching dengan berbantuan alat peraga "kartu pintar" pada materi prisma dan limas kelas VIII SMP Negeri 1 Pandaan Tahun Pelajaran 2017/2018 mengunakan metode kombinasi (mixed methods) dengan desain rancangan metode campuran eksperimental. Analisis metode kuantitatif pada tahap pertama yaitu (1) Tes: data yang diperoleh dari hasil pre-test dan post-test kemampuan penalaran matematis menggunakan model pembelajaran Reciprocal Teaching dengan berbantuan alat peraga "kartu pintar"; (2) Analisis statistik: mencari peningkatan kemampuan penalaran matematis peserta didik menggunakan model pembelajaran Reciprocal Teaching dengan berbantuan alat peraga "kartu pintar" dengan uji t, selanjutnya analisis metode kualitatif pada tahap kedua yaitu: (1) Observasi, wawancara, dan catatan lapangan: data yang diperoleh dari informan dan pengamatan dalam proses pembelajaran menggunakan model pembelajaran Reciprocal Teaching dengan berbantuan alat peraga "kartu pintar"; (2) Reduksi data: memilih data yang penting, membuat kategori, dan membuang yang tidak diperlukan; (3) menyajikan data kuantitatif dan kualitatif ke dalam pola, tabel atau grafik; (4) Konklusi/verifikasi: penarikan kesimpulan dan verifikasi dari penelitian.

Menurut Sugiyono (2015:397) mengemukakan bahwa metode penelitian kombinasi adalah metode penelitian yang mengombinasikan atau menggabungkan metode penelitian kuantitatif dan kualitatif yang dilakukan bersama-sama dalam satu penelitian untuk mendapatkan hasil yang komprehensif, valid, reliabel dan objektif. Dalam penelitian metode kombinasi, peneliti menggunakan jenis penelitian rancangan metode campuran eksperimental. Rancangan metode campuran eksperimental adalah membungkus suatu rancanagan metode campuran dasar kedalam strategi yang lebih lanjut, yaitu dengan menambahkan proses-proses kedalam prosedur eksperimen (Creswell, 2015:1112). Pada rancangan metode campuran eksperimental ini, data kualitatif dapat ditambahkan sebelum eksperimen, selama eksperimen berlangsung, dan setelah eksperimen. Data kualitatif berfungsi sebagai penambah atau pendukung prosedur eksperimental. Sementara itu, data kuantitatif digunakan untuk mengetahui apakah eksperien tersebut memiliki dampak atau tidak.

\section{HASIL}

Dalam penelitian ini peneliti menggunakan tes berupa tes uraian yang sudah diuji validitas dan reliabilitasnya untuk digunakan sebagai instrumen pengumpulan data kuantitatif. Sebelum tes tersebut digunakan terlebih dahulu dilakukan validasi logis dan validasi empiris, untuk memperoleh soal tes yang valid. Validasi logis dilakukan oleh ahli yaitu dosen pendidikan matematika UNISMA dan praktisi yaitu guru matematika SMP Negeri 1 Pandaan. Sedangkan pengumpulan data kualitatif menggunakan hasil observasi, wawancara, dan catatan lapangan.

Berdasarkan hasil validasi yang dilakukan oleh validator, terdapat 4 butir soal yang akan diuji dan berdasarkan hasil validasi tersebut diperoleh bahwa soal pre-test dan post-test kemampuan penalaran matematis sudah valid dan dapat digunakan dengan sedikit revisi. Dari empat butir soal tersebut mengukur 4 indikator penalaran matematis yang digunakan dalam penelitian ini yaitu (1) mengajukan dugaan; (2) melakukan manipulasi matematika; (3) menarik kesimpulan, menyusun bukti, memberikan alasan atau bukti terhadap kebenaran solusi; (4) menemukan pola atau sifat dari gejala matematis untuk membuat generalisasi.

\section{Hasil Analisis Kuantitatif}

Berdasarkan analisis data kuantitatif kemampuan penalaran matematis peserta didik kelas eksperimen yang diajar menggunakan model pembelajaran Reciprocal Teaching dengan berbantuan alat peraga "kartu pintar" dapat dilihat pada Tabel 1.

Tabel 1 Nilai Mean dan Standart Deviation

\begin{tabular}{|c|c|c|c|c|c|c|}
\hline \multirow{2}{*}{ Model Pembelajaran } & \multicolumn{2}{|l|}{ Mean } & \multicolumn{2}{|c|}{ Standar Deviasi } & \multirow{2}{*}{$\begin{array}{l}\text { Jumlah } \\
\text { Didik }\end{array}$} & \multirow[t]{2}{*}{ Peserta } \\
\hline & Pre-test & Post-test & Pre-test & Post-test & & \\
\hline $\begin{array}{l}\text { Reciprocal Teaching } \\
\text { dengan Berbantuan Alat } \\
\text { Peraga "Kartu Pintar" }\end{array}$ & 26,00 & 78,00 & 10,120 & 8,248 & 32 & \\
\hline
\end{tabular}

Hasil analisis tes kemampuan penalaran matermatis dapat dilihat pada Tabel 2. 
Tabel 2 Hasil Analisis Tes Kemampuan Penalaran Matematis

\begin{tabular}{|c|c|c|}
\hline \multirow{3}{*}{ No } & \multirow{3}{*}{ Hasil Analisis Tes } & Jumlah \\
\hline & & Kelas \\
\hline & & Eksperimen \\
\hline 1. & Rata-rata & 78,00 \\
\hline 2. & Nilai tertinggi & 92 \\
\hline 3. & Nilai terendah & 65 \\
\hline 4. & Jumlah peserta didik yang tuntas & 23 \\
\hline 5. & Jumlah siswa peserta didik yang belum tuntas & 9 \\
\hline 6. & Presentase peserta didik yang tuntas & $71,875 \%$ \\
\hline 7. & Presentase peserta didik yang belum tuntas & $28,125 \%$ \\
\hline
\end{tabular}

Dari Tabel 2 dapat diketahui bahwa peserta didik kelas eksperimen memperoleh nilai $\geq$ 75 (tuntas) berjumlah 23 orang atau mencapai $71,875 \%$ sedangkan yang memperoleh nilai $<75$ (tidak tuntas) berjumlah 9 orang atau mencapai $28,125 \%$.

Berdasarkan Tabel 1 dan 2, maka dapat disimpulkan bahwa terdapat terdapat peningkatan antara kemampuan penalaran matematis sebelum dan sesudah menggunakan model pembelajaran Reciprocal Teaching dengan berbantuan alat peraga "kartu pintar".

\section{Hasil Analisis Kualitatif}

Setelah nilai post-test diketahui maka diperoleh subjek wawancara yang berjumlah enam peserta didik. enam peserta didik tersebut terdiri dari dua peserta didik kelompok tinggi, dua peserta didik kelompok sedang, dan dua peserta didik kelompok rendah baik pada kelas eksperimen. Klasifikasi penilaian tersebut berdasarkan klasifikasi penilaian yang digunakan sekolah yaitu berdasarkan PAN (Pacuan Aturan Normal). Klasifikasi penilaian ditunjukkan pada Tabel 3.

\begin{tabular}{|c|c|}
\hline Rentang Nilai & \\
\hline Kelas Eksperimen & каasıiাKası \\
\hline $81-100$ & Tinggi \\
\hline $67-80$ & Sedang \\
\hline $0-66$ & Rendah \\
\hline
\end{tabular}

Berdasarkan analisis data kualitatif yang diperoleh dari hasil wawancara dengan subjek kemampuan penalaran matematis tinggi, sedang, dan rendah baik diperoleh hasil yang ditunjukkan pada Tabel 4.

Tabel 4 Hasil Wawancara

\begin{tabular}{ll}
\hline No. & Kelas Eksperimen \\
\hline 1 & Sebesar 66,67, \% Subjek menyatakan bahwa mereka merasa \\
& senang mengikuti pembelajaran menggunakan model \\
& pembelajaran reciprocal teaching dengan berbantuan alat peraga \\
& "kartu pintar" \\
\hline 2 & Sebesar 83,33\% Subjek menyatakan bahwa mereka merasa senag \\
& mengikuti proses pembelajaran menggunakan model pembelajaran \\
& reciprocal teaching dengan berbantuan alat peraga "kartu pintar" \\
& karena mereka belajar bagaimana menjadi seorang guru dan \\
& pembelajaran tidak membosankan \\
\hline 3 & Sebesar 83,33\% Subjek sudah memenuhi empat indikator \\
& kemampuan penalaran matematis sehingga dapat menjawab soal \\
& dengan benar
\end{tabular}

Dari hasil wawancara pada Tabel 4, maka dapat disimpulkan bahwa, (1) secara kualitatif model pembelajaran Reciprocal Teaching dengan berbantuan alat peraga "kartu pintar" direspon dengan baik, dan peserta didik merasa senang, (2) secara keseluruhan kemampuan penalaran matematis peserta didik lebih baik sesudah menggunakan model pembelajaran Reciprocal Teaching dengan berbantuan alat peraga "kartu pintar" dan peserta didik tidak merasa bosan dengan model pembelajaran yang diajarkan, (3) model model pembelajaran Reciprocal Teaching dengan berbantuan alat peraga "kartu pintar" dapat meningkatkan kemampuan penalaran matematis, sehingga sebagian besar sudah memenuhi keempat indikator dan dapat menjawab 
soal dengan benar. Jadi hasil penelitian kualitatif juga menunjukkan adanya peningkatan kemampuan penalaran matematis antara sebelum dan sesudah menggunakan model pembelajaran Reciprocal Teaching dengan berbantuan alat peraga "kartu pintar".

Hasil penelitian kualitatif tersebut mendukung, membuktikan dan melengkapi hasil penelitian kuantitatif yang juga menunjukkan adanya peningkatan kemampuan penalaran matematis dengan perhitungan menggunakan software minitab 17 diperoleh nilai p_value = 0,000. Jelas $p \_v a l u e=0,000<0,05$ sehingga $H 0$ ditolak. Artinya terdapat peningkatan kemampuan penalaran matematis peserta didik yang memperoleh materi prisma dan limas sisi datar menggunakan model pembelajaran Reciprocal Teaching dengan berbantuan alat peraga "kartu pintar".

\section{Hasil Analisis Data Kuantitatif dan Kualitatif}

Analisis data kualitatif dan data kuantitatif dapat dilakukan dengan cara membandingkan data kuantitatif dan data kualitatif tentang kemampuan penalaran matematis. Dalam penelitian kuantitatif, berdasarkan hasil uji hipotesisi menyatakan bahwa terdapat peningkatan kemampuan penalaran matematis antara kemampuan awal peserta didik dengan kemampuan akhir peserta didik dan pada penilitian kualitatif berdasarkan hasil analisis per indikator menyatakan bahwa terdapat peningkatan kemampuan penalaran matematis antara kemampuan awal peserta didik dengan kemampuan akhir peserta didik sehingga penelitian kualitatif yang dilakukan pada tahap kedua hasil penelitian kualitatif yang dapat mendukung, melengkapi, memperkuat data kuantitatif tentang kemampuan penalaran matematis peserta didik.

Oleh karena itu, berdasarkan penjabaran di atas terdapat peningkatan kemampuan penalaran matematis antara kuantitatif dan kualitatif sehingga dapat disimpulkan bahwa model pembelajaran Reciprocal Teaching dengan berbantuan alat peraga "kartu pintar" dengan materi prisma dan limas sisi datar prisma dan limas dapat meningkatkan kemampuan pealaran matematis peserta didik kelas eksperimen.

\section{PEMBAHASAN}

Berdasarkan hasil analisis data pre-test kemampuan penalaran matematis diperoleh bahwa sampel berdistribusi normal. Hasil tes kemampuan penalaran matematis peserta didik diukur menggunakan hasil pre-test dan post-test. Berdasarkan hasil pengujian hipotesis diperoleh bahwa $\mathrm{H}_{0}$ ditolak, artinya terdapat peningkatan antara kemampuan penalaran matematis sebelum dan sesudah menggunakan model pembelajaran Reciprocal Teaching dengan berbantuan alat peraga "kartu pintar".

Peningkatan antara kemampuan penalaran matematis sebelum dan sesudah menggunakan model pembelajaran Reciprocal Teaching dengan berbantuan alat peraga "kartu pintar" dilihat dari perbedaan yang signifikan antar pre-test dan post-test. Pada kelas eksperimen nilai tertinggi kemampuan awal (pre-test) penalaran matematis peserta didik sebesar 47 dan terendah 18 serta nilai rata-rata pre-test sebesar 26,00. Sedangkan pada kemampuan akhir (post-test) penalaran matematis nilai tertinggi peserta didik sebesar 92 dan terendah 65 serta nilai rata-rata post-test sebesar 78,00. Berdasarkan hasil observasi dan catatan lapangan terlihat bahwa peserta didik dengan kemampuan penalaran tinggi lebih aktif dalam pembelajaran, serta berdasarkan hasil wawancara persentase peserta didik kelas eksperimen yang memenuhi keempat indikator penalaran matematis. Dari hasil tersebut maka dapat disimpulkan bahwa pembelajaran menggunakan model pembelajaran Reciprocal Teaching dengan berbantuan alat peraga "kartu pintar" lebih efektif karena dapat menumbuhkan bakat peserta didik berbicara dan mengembangkan sikap aktif dalam diskusi kelompok. Hal ini sesuai dengan pendapat Shoimin (2014:156) bahwa salah satu kelebihan model pembelajaran Reciprocal Teaching adalah dapat memupuk keberanian berpendapat dan berbicara di depan kelas, menumbuhkan sikap menghargai guru karena peserta didik akan merasakan perasa guru pada saat mengadakan pembelajaran terutama pada saat peserta didik ramai dan kurang meperhatikan.

Berdasarkan penelitian secara kualitatif ada peningkatan antara kemampuan penalaran matematis sebelum dan sesudah menggunakan model pembelajaran Reciprocal Teaching dengan berbantuan alat peraga "kartu pintar" sehingga hasil kualitatif dapat mendukung hasil penelitian kuantitatif, hal ini didukung oleh teori mixed method dengan desain sequential explanatory bahwa data kuantitatif pada tahap awal didukung oleh data kualitatif pada tahap akhir. 


\section{SIMPULAN DAN SARAN}

Berdasarkan hasil penelitian yang dilaksanakan, diperoleh simpulan sebagai berikut: (1) Berdasarkan hasil analisis data kuantitatif dengan uji hipotesis menggunakan software minitab 17 diperoleh nilai $p_{-}$value $=0,000$. Karena nilai $p_{\text {_value }}=0,000<0,005$ maka $H_{0}$ ditolak atau $H_{1}$ diterima. Hal ini berarti dapat disimpulkan bahwa terdapat peningkatan antara kemampuan penalaran matematis sebelum dan sesudah menggunakan model pembelajaran Reciprocal Teaching dengan berbantuan alat peraga "kartu pintar" pada materi prisma dan limas kelas VIII di SMP Negeri 1 Pandaan; (2) Berdasarkan analisis data kualitatif yang diperoleh dari wawancara dapat disimpulkan bahwa $66,67 \%$ peserta didik merasa senang diajar dengan menggunakan model pembelajaran Reciprocal Teaching dengan berbantuan alat peraga "kartu pintar". Dari analisis data wawancara sebesar $83,33 \%$ peserta didik sudah memenuhi keempat indikator kemampuan penalaran matematis. Kemampuan penalaran matematis peserta didik yang diajar dengan menggunakan model pembelajaran Reciprocal Teaching dengan berbantuan alat peraga "kartu pintar" termasuk dalam kategori baik yang dapat dilihat dari hasil rata-rata posttest menunjukkan nilai sebesar 78,00. Dari beberapa analisis data tesebut menunjukkan bahwa kemampuan penalaran matematis meningkat setelah penerapan model pembelajaran Reciprocal Teaching dengan berbantuan alat peraga "kartu pintar".

Dari hasil penelitian ini diharapkan dapat memberikan sumbangan ide-ide dalam upaya meningkatkan kualitas pembelajaran matematika, khususnya dalam melatih kemampuan penalaran matematis peserta didik. Oleh karena itu, diberikan saran sebagai berikut: (1) Bagi guru: model pembelajaran Reciprocal Teaching dengan berbantuan alat peraga "kartu pintar" membutuhkan waktu yang cukup lama, untuk itu bagi guru yang hendak menggunakan model pembelajaran Reciprocal Teaching dengan berbantuan alat peraga "kartu pintar" dalam pembelajaran di kelas diharapkan dapat mengatur waktu lebih baik lagi, mempersiapkan dan melaksanakan pembelajaran dengan seefektif mungkin agar pembelajaran dapat diselesaikan dengan baik dan tepat waktu, dan saat berdiskusi kelompok guru harus membimbing peserta didik agar konsep materi yang akan mereka temukan sesuai dengan tujuan pembelajaran, selain itu model pembelajaran Reciprocal Teaching dengan berbantuan alat peraga "kartu pintar" akan menjadi membosankan jika peserta didik yang ditunjuk sebagai guru tidak siap dan akan membuat peserta didik tersebut tidak menyukai pembelajaran ini; (2) Bagi peneliti selanjutnya: bagi peneliti selanjutnya yang akan mengadakan penelitian tentang model pembelajaran model Reciprocal Teaching dengan berbantuan alat peraga "kartu pintar" terhadap kemampuan penalaran matematis, disarankan penelitian ini dapat dilengkapi dengan meneliti aspek yang belum terjangkau seperti meneliti kemampuan matematik lain, meneliti tentang peningkatan ataupun pengaruh, dan diharapkan untuk menggunakan pada materi yang lain serta pada jenjang pendidikan yang berbeda.

\section{DAFTAR RUJUKAN}

Amin, S. (2006). Dasar-Dasar dan Proses Pembelajaran Matematika 1. Semarang: Jurusan Matematika FMIPA Universitas Negeri Semarang.

IEA. (2016). TIMSS 2015 International Result in Mathematics. http://timss2015.org/wpcontent/uploads/filebase/full\%20pdfs/T15-InternationalResults-in-Mathematics-Grade4.pdf.

Nasaruddin. (2015). Media Dan Alat Peraga Dalam Pembelajaran Matematika. Al-Khwarizmi, 3(2), 21-30.

OECD. (2016). PISA 2015 Result in Focus. https://www.oecd.org/pisa/pisa-2015-results-infocus.pdf.

Peraturan Menteri Pendidikan Nasional Republik Indonesia Nomor 22 Tahun 2006 tentang Standar Isi untuk Satuan Pendidikan Dasar dan Menengah. (2006). Jakarta: Armas Duta Jaya.

Pusat Penilaian Pendidikan Badan Penelitian Dan Pengembangan. (2016). TIMSS infographic. http://puspendik.kemdikbud.go.id/seminar/upload/Hasil\%20Seminar\%20Puspendik\%202 016/TIMSS\%20infographic.pdf.

Shoimin, A. (2014). 68 Model Pembelajaran Inovatif dalam Kurikulum 2013. Yogyakarta: ArRuzz Media.

Sugiyono. (2015). Metode Penelitian Kombinasi (Mixed Methods). Bandung: Alfabeta.

Triastuti, R., Asikin, M., \& Wijayanti, K. (2013). Keefektifan Model CIRC Berbasis Joyful Learning Terhadap Kemampuan Penalaran Matematis Siswa SMP. Jurnal Matematika FMIPA UNNES, 4 (2) 182-188. 
Undang-Undang Republik Indonesia Nomor 20 Tahun 2003 tentang Sistem Pendidikan Nasional. (2003). Jakarta: Armas Duta Jaya. 